\title{
Antimicrobial activity of Aegiphila sellowiana Cham., Lamiaceae, against oral pathogens
}

\author{
Marcele A. Ferreira, ${ }^{1}$ Tatiane C. Carvalho, ${ }^{1}$ Izabel C. C. Turatti, ${ }^{2}$ Niege A. J. C. Furtado, ${ }^{1,3}$ \\ Carlos H. G. Martins, ${ }^{1}$ Norberto P. Lopes, ${ }^{2}$ Wilson R. Cunha, ${ }^{1}$ Antonio E. M. Crotti ${ }^{*}, 1$
}

\author{
${ }^{1}$ Núcleo de Pesquisas em Ciências Exatas e Tecnológicas, Universidade de Franca, Av. Dr. Armando Salles de \\ Oliveira, 201, 14404-600 Franca-SP, Brazil \\ ${ }^{2}$ Departamento de Física e Química, Faculdade de Ciências Farmacêuticas de Ribeirão Preto, Universidade de \\ São Paulo, 140404-903 Ribeirão Preto-SP, Brazil \\ ${ }^{3}$ Departamento de Ciências Farmacêuticas, Faculdade de Ciências Farmacêuticas de Ribeirão Preto, \\ Universidade de São Paulo, 140404-903 Ribeirão Preto, SP, Brazil.
}

\begin{abstract}
RESUMO: "Atividade antimicrobiana de Aegiphila sellowiana Cham., Lamiaceae, contra patógenos orais". A atividade antimicrobiana de Aegiphila sellowiana Cham., Lamiaceae, contra patógenos da cavidade bucal foi avaliada empregando-se o método de microdiluição em caldo, segundo o protocolo CLSI M7-A7, utilizando-se clorexidina como controle positivo. O extrato etanólico bruto das partes aéreas de $A$. sellowiana, obtido por maceração, exibiu atividade contra os microrganismos testados neste trabalho, entretanto, os valores de CIM (concentração inibitória mínima) aumentaram após a partição com $n$-hexano, diclorometano e acetato de etila. Entre as frações testadas, a fração n-hexânica foi a mais efetiva contra os patógenos bucais avaliados, com valores de CIM entre 140 e $350 \mu \mathrm{g} / \mathrm{mL}^{-1}$. Dados obtidos por CG-EM revelaram que ésteres de ácidos graxos, esteróides e hidrocarbonetos sesquiterpênicos alifáticos são os constituintes majoritários desta fração. Embora esses compostos possam ser os responsáveis pela atividade da fração $n$-hexânica, outros constituintes químicos presentes nas frações em diclorometano, acetato de etila e hidroalcoólica podem potencializar suas atividades no extrato bruto.
\end{abstract}

Unitermos: Aegiphila sellowiana, antividade antimicrobiana, CG-EM, patógenos orais, Lamiaceae.

\begin{abstract}
The antimicrobial activity of Aegiphila sellowiana Cham., Lamiaceae, against oral pathogens is reported. The Minimal Inhibitory Concentrations (MICs) for inhibiting the microorganisms growth were determined using the broth microdilution method from the CLSI M7-A7 protocol. Chlorhexidine was used as the positive control. The ethanol crude extract of the aerial parts of $A$. sellowiana exhibited activity against the microorganisms tested in this work; however, the activity decreased after partition with $n$-hexane, dichloromethane, and ethyl acetate. Among the tested fractions, the n-hexane fraction was found to be the most effective against the evaluated oral pathogens. GC-MS analysis of this latter fraction revealed that fatty acids esters, steroids, and aliphatic sesquiterpene hydrocarbons are its major constituents. These compounds may be responsible for the activity of the $n$-hexane fraction, but other chemical constituents of the dichloromethane, ethyl acetate, and hydroalcoholic fraction may potentialize their activities in the crude extract.
\end{abstract}

Keywords: Aegiphila sellowiana, antimicrobial activity, GC-MS, oral pathogens, Lamiaceae.

\section{INTRODUCTION}

Dental caries and periodontal diseases are associated with oral pathogens, mainly bacteria (Botelho et al., 2007). Both of the cariogenic and periodontopathic bacteria present in the oral cavity form an adherent, structurally- and functionally-organized biofilm (Marsh, 2006). Strategies to control caries include inhibition of the biofilm development (e.g. prevention of the attachment of cariogenic bacteria, delivery of effective antimicrobials etc.) or enhacement of the host defenses (Gilbert et al., 2002). Mechanical methods of oral hygiene such as brushing and flossing are the most commonly applied approaches for routine denture biofilm control (Sharma et al., 2004; Barnett, 2006). However, studies have indicated that most people fail to maintain a sufficient level of 
biofilm control by brushing only, so that chemotherapeutic mouth rinses may play a key role as adjuncts to daily home care (Santos, 2003).

Several plant derivatives, including crude extracts (Wu et al., 2001; AbdElRahman et al., 2002), essential oils (Takarada et al., 2004; Prabuseenivasan et al., 2006), and pure compounds (Silva et al., 2007) have been evaluated with respect to their antimicrobial effects against oral pathogens. These derivatives have attracted the interest of many research groups, since they may be employed in the development of new mouth rinses for oral hygiene.

As part of our ongoing research on the antimicrobial activities of Brazilian plants and bioactive natural compounds (Oliveira et al., 2007; Silva et al., 2007; Cunha et al., 2007), and because previous reports documenting the antimicrobial activity of Verbenaceae species against oral pathogens (Chung et al., 2004; Botelho et al., 2007), we have investigated the in vitro antimicrobial potential of Aegiphila sellowiana Cham., Lamiaceae, popularly known as "tamanqueira". This species is an arboreous (or sometimes arbustive) species, which naturally occurs in the tropical and subtropical regions of America, mainly in Brazil. Despite its use in Brazilian folk medicine as an anti-inflammatory agent and against snake venom (Leitão et al., 1992), there are no previous phytochemical or pharmacological investigations regarding $A$. sellowiana.

\section{MATERIAL AND METHODS}

\section{Plant material}

Aerial parts of $A$. sellowiana were collected near Usina Mascaranhas, Peixoto-MG, Brazil (20o16'S, 47o5'W G) by Wilson R. Cunha in December 2004 and identified by Prof. Alba R. de Araújo of the Botany Department of Universidade de Franca, Franca-SP, Brazil. A voucher specimen (\# UEC 15320) has been deposited at the Herbarium of the Biology Institute, UNICAMP, Campinas - SP, Brazil.

\section{Extraction and fractionation}

Aerials parts of the plant $(1.2 \mathrm{~kg})$ were dehydrated, powdered, and exhaustively extracted by maceration with ethanol (Merck, Darmstadt, Germany) at $25{ }^{\circ} \mathrm{C}$. A sample $(25 \mathrm{~g})$ of the resulting extract was dissolved with a minimum volume of a mixture of ethanol and distilled water $(9: 1 \mathrm{v} / \mathrm{v})$, and it was successively partitioned with $n$-hexane, $\mathrm{CH}_{2} \mathrm{Cl}_{2}$, and ethyl acetate $(3 \times 500 \mathrm{~mL})$ from Merck (Darmstadt, Germany).

\section{Antimicrobial assays}

The minimum inhibitory concentration (MIC) values of the crude extract and its fractions were determined by using the broth microdilution method (CLSI, 2006) in 96-well microplates. The following standard strains from the ATCC were used: Enterococcus faecalis (ATCC 4082), Streptococcus salivarius (ATCC 25975), Streptococcus sobrinus (ATCC 33478), Streptococcus mutans (ATCC 25175), Streptococcus mitis (ATCC 49456), Streptococcus sanguinis (ATCC 10556) and Lactobacillus casei (ATCC 11578). Individual $24 \mathrm{~h}$ colonies from blood agar (Difco Labs, Detroit, Mich, USA) were suspended in 10.0 $\mathrm{mL}$ of tryptic soy broth (Difco). The standardization of each microorganism suspension was carried out using spectrophotometer (Femto, São Paulo, Brazil) at wavelength $(\lambda)$ of $625 \mathrm{~nm}$ to match the transmittance of 81 , equivalent to $0.5 \mathrm{McF}$ arland scale $\left(1.5 \times 10^{8} \mathrm{CFU} /\right.$ $\mathrm{mL})$ and dilution at final concentration of the $5 \times 10^{5}$ CFU/mL. The samples were dissolved in DMSO (Merck, Darmstadt, Germany), at $1 \mathrm{mg} / \mathrm{mL}$, and they were then diluted in tryptic soy broth (Difco) so that concentrations in the range 400 to $20 \mu \mathrm{g} / \mathrm{mL}$ would be achieved. The final DMSO concentration was $4 \%(\mathrm{v} / \mathrm{v})$, and this solution was used as negative control (concentrations ranging from 4 to $1 \%$ ). One inoculated well was included, so as to control the adequacy of the broth for organism growth. One non-inoculated well free of antimicrobial agent was also included to ensure medium sterility. Two-fold serial dilutions of chlorhexidine (Sigma) were made in tryptic soy broth (Difco) to achieve concentrations ranging from 5.9 to $0.0115 \mu \mathrm{g} / \mathrm{mL}$ and were used as positive control. The microplates (96 well) were sealed with parafilm and incubated at $37{ }^{\circ} \mathrm{C}$ for $24 \mathrm{~h}$. After that, $30 \mu \mathrm{L}$ of $0.02 \%$ resazurin (Stl. Louis, MO, USA) aqueous solution was poured in each microplate reservoir, to indicate the microorganism viability (Palomino et al., 2002). The MIC was determined as the lowest concentration of the extract or of its fractions capable of inhibiting microorganism growth. Three replicates were made for each microorganism.

\section{Gas chromatography-mass spectrometry}

Gas chromatography-mass spectrometry analysis was performed on a Shimadzu GCMS model QP2010 apparatus. Helium (99.999\%) was used as the carrier gas at a constant flow rate of $1.62 \mathrm{~mL} / \mathrm{min}$. A DB5-MS $(30$ $\mathrm{m} \times 0.25 \mathrm{~mm}$ i.d, film thickness $0.25 \mathrm{~m}, 5 \%$ crosslinked phenyl-methylpolysiloxane) column was employed. The column temperature was programmed to rise from $105^{\circ} \mathrm{C}$ (0 min hold) to $200{ }^{\circ} \mathrm{C}$ at $13{ }^{\circ} \mathrm{C} / \mathrm{min}$, from $200{ }^{\circ} \mathrm{C}(0 \mathrm{~min}$ hold) to $240{ }^{\circ} \mathrm{C}$ at $5^{\circ} \mathrm{C} / \mathrm{min}$, from 240 (20 min hold) to 280 ${ }^{\circ} \mathrm{C}$ at $10^{\circ} \mathrm{C} / \mathrm{min}$, and it was finally maintained at $280{ }^{\circ} \mathrm{C}$ for $10 \mathrm{~min}$. The injector temperature was set at $250{ }^{\circ} \mathrm{C}$, with a split ratio of 1:60. The column outlet was inserted directly into the electron ionization source block, operating at 70 $\mathrm{eV}$. The scan range was 40-500 Da. The identification of the individual components was carried out by comparing the mass spectra data with those of the spectra library Wiley. 


\section{RESULTS}

The results of the in vitro antimicrobial activity of the crude ethanol extract of $A$. sellowiana (AS) and its $n$-hexane $\left(\mathrm{AS}_{1}\right)$, dichloromethane $\left(\mathrm{AS}_{2}\right)$, ethyl acetate $\left(\mathrm{AS}_{3}\right)$, and ethanol:water $\left(\mathrm{AS}_{4}\right)$ fractions are shown in Table 1.

Table 1. Antimicrobial activity of A. sellowiana determined by the broth microdilution method.

\begin{tabular}{lcccccc}
\hline & \multicolumn{6}{c}{ Minimum inhibitory concentration $(\mu \mathrm{g} / \mathrm{mL})$} \\
\cline { 2 - 6 } & Chlorexidine & $\mathrm{AS}$ & $\mathrm{AS}_{1}$ & $\mathrm{AS}_{2}$ & $\mathrm{AS}_{3}$ & $\mathrm{AS}_{4}$ \\
\hline $\begin{array}{l}\text { Enterococcus } \\
\text { faecalis }\end{array}$ & 0.3688 & 200 & $*$ & $*$ & $*$ & $*$ \\
Lactobacillus casei & 0.0230 & $*$ & 150 & $*$ & $*$ & $*$ \\
$\begin{array}{l}\text { Streptococcus mitis } \\
\text { Streptococcus }\end{array}$ & 0.3688 & 50 & 140 & 400 & 400 & $*$ \\
$\begin{array}{l}\text { mutans } \\
\text { Streptococcus }\end{array}$ & 0.3688 & 200 & 250 & 400 & $*$ & $*$ \\
sanguinis & 0.0922 & 70 & 140 & $*$ & 400 & $*$ \\
$\begin{array}{l}\text { Streptococcus } \\
\text { sobrinus }\end{array}$ & 0.0115 & 80 & 250 & $*$ & $*$ & $*$ \\
$\begin{array}{l}\text { Streptococcus } \\
\text { salivarius }\end{array}$ & 0.0461 & 80 & 350 & $*$ & $*$ & $*$ \\
\hline
\end{tabular}

*Inactive in the evaluated concentrations. AS refers to the crude ethanol extract of $A$. sellowiana; $\mathrm{AS}_{1}, \mathrm{AS}_{2}, \mathrm{AS}_{3}$ and $\mathrm{AS}_{4}$ refer to the $n$-hexane, dichloromethane, ethyl acetate and ethanol:water<smiles>[R]CCCC(C)CCCC(C)CCCC(C)C</smiles>
$1-3$<smiles>[R]O[C@H]1CC[C@]2(C)C(=CC[C@@H]3[C@@H]2CC[C@]2(C)[C@@H]([R])CC[C@@H]32)C1</smiles>

4-5<smiles>[R]C[C@H](C)[C@H](C)CC[C@H](CC)C(C)C</smiles>

4<smiles>CCCCCCCCC</smiles>

1<smiles>CCC(/C=C/C(C)C)C(C)C</smiles>

5

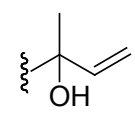

2<smiles>C=CC(=C)C</smiles>

3<smiles>CCC(CC[C@@H](C)C1CCC2C(=O)C=C3C=CCCC3(C)[C@@H]2C1C)C(C)C</smiles>

most active fraction was $\mathrm{AS}_{1}$. On the other hand, at the evaluated concentrations, some fractions did not exhibit any activity against some bacteria and the MIC values were higher than $400 \mu \mathrm{g} / \mathrm{mL}$. These results clearly demonstrate that AS fractionation results in a decrease of the in vitro antimicrobial activity.

The $n$-hexane fraction $\left(\mathrm{AS}_{1}\right)$ was the most active one. Its activity may be related to the presence of lipophilic compounds, mainly long chain fatty acids, which are the major constituents of this fraction. Lipophilicity is known to be closely related to permeation through a lipidic coating of bacteria (Tokuyama et al., 2001). These compounds are often identified in natural extracts that exhibit antimicrobial properties (Petschow et al., 1996; Gyles et al., 2002). However, it is likely that the effects of these compounds on oral pathogens are potentialized by synergistic/additive effects of other minor chemical constituents present in $\mathrm{AS}_{1}$, as well as by other compounds present in $\mathrm{AS}_{2}, \mathrm{AS}_{3}$, and $\mathrm{AS}_{4}$.

In summary, the results obtained in this study demonstrate the antimicrobial potential of the crude ethanol extract of the aerial parts of A. sellowiana against oral pathogens. 


\section{ACKNOWLEDGEMENT}

The authors thank the Brazilian foundations FAPESP (Proc. 07/54241-8) and CAPES for the financial support.

\section{REFERENCES}

AbdElRahman HF, Skaug N, Francis GW 2002. In vitro antimicrobial effects of crude miswak extracts on oral pathogens. Saudi Dental J 14: 26-32.

Barnett L 2006. The rationale for the daily use of an antimicrobial mouthrinse. DDS J Am Dent Assoc 137 suppl 3: 16S$21 \mathrm{~S}$.

Botelho MA, Nogueira NA, Bastos GM, Fonseca SG, Lemos TL, Matos FJ, Montenegro D, Heukelbach J, Rao VS, Brito GA 2007. Antimicrobial activity of the essential oil from Lippia sidoides, carvacrol, and thymol against oral pathogens. Braz J Med Biol Res 40: 349-356.

CLSI 2006. Methods for Dilution Antimicrobial Susceptibility Tests for Bacteria That Grow Aerobically; Approved Standard-Seventh Edition. CLSI document M7-A7 (ISBN 1-56238-587-9). CLSI, 940 West Valley Road, Suite 1400, Wayne, Pennsylvania 19087-1898 USA.

Chung PY, Chung LY, Ngeow YF, Goh SH, Imiyabir Z 2004. Antimicrobial activities of Malaysian plant species. Pharm Biol 42: 292-300.

Cunha LCS, Silva MLA, Furtado NAJC, Vinhólis AHC, Martins CHG, Silva-Filho AA, Cunha WR 2007. Antibacterial activity of triterpene acids and semi-synthetic derivatives against oral pathogens. Z Naturforsch 62: 668-672.

Gilbert P, Maira-Litran T, McBain AJ, Rickard AH, Whyte FW 2002. The physiology and collective recalcitrance of microbial biofilm communities. Adv Microb Physiol 46: 203-255.

Gyles RK, Marquis RE, Phan, TN 2002. Antimicrobial actions of glycerol fatty-acid esters for oral streptococci. IADR/AADR/CADR 80 $0^{\text {th }}$ General Session, San Diego, Microbiology/Immunology and Infection Control Program, 1486.

Leitão SG, Kaplan MAC, Delle Monache F, Akihisa T, Tamura T 1992. Sterols and sterol glucosides from two Aegiphila species. Phytochemistry 31: 2813-2817.

Marsh PD 2006. Dental plaque as a biofilm and a microbial community - implications for health and disease. BMC Oral Health 6 (Suppl 1): S1-S14.

Oliveira GF, Furtado NAJC, Silva Filho AA, Martins CHG, Bastos JK, Cunha WR, Silva MLA 2007. Antimicrobial activity of Syzygium cumini (Myrtaceae) leaves extract. Braz J Microbiol 38: 381-384.

Palomino JC, Martin A, Camacho M, Guerra H, Swings J, Portaels S 2002. Resazurin microtiter assay plate: simple and inexpensive method for detection of drug resistance in Mycobacterium tuberculosis. Antimicrob Agents Chemother 46: 2720-2722.

Petschow BW, Batema RP, Ford LL 1996. Susceptibility of Helicobacter pylori to bactericidal properties of mediumchain monoglycerides and free-fatty acids. Antimicrob Agents Chemother 40: 302-306.

Prabuseenivasan S, Jayakumar M, Ignacimuthu S 2006. In vitro antibacterial activity of some plant essential oils. BMC Complement Altern Med 6: 39-46.
Rios JL, Recio MC 2005. Medicinal plants and antimicrobial activity. J Ethnopharmacol 100: 80-84.

Santos A 2003. Evidence-based control of plaque and gingivitis. J Clin Periodontol suppl 5: 13-16.

Sharma N, Charges CH, Lynch MC, Qaqish J, McGuire JA, Galustians JG, Kumar LD 2004. Adjunctive benefit of an essential oil-containing mouthrinse in reducing plaque and gingivitis in patients who brush and floss regularly. $J$ Am Dent Assoc 135: 496-504.

Silva MLA, Coimbra H, Pereira AC, Almeida VA, Lima TC, Costa ES, Vinholis AHC, Royo VA, Silva R, Silva Filho AAS Cunha WR, Furtado NAJC, Martins CHG, Carvalho TC, Bastos JK 2007. Evaluation of Piper cubeba extract (-)-cubebin and its semi-synthetic derivatives against oral pathogens. Phytotherapy Res 21: 420-422.

Takarada K, Kimizuka R, Takahashi N, Honma K, Okuda K, Kato T 2004. A comparison of the antibacterial efficacies of essential oils against oral pathogens. Oral Microbiol Immunol 19: 61-64.

Tokuyama R, Takahashi Y, Tomita Y, Tsobouchi M, Yoshida T, Iwasaki N, Kado N, Okezaki E, Nagata O 2001. Structureactivity relationship (SAR) studies on oxazolidinone antibacterial agents. 2. Relationship between lipophilicity and antibacterial activity in 5-thiocarbonyl oxazolidinones. Chem Pharm Bull 49: 353-360.

Wu IA, Darout N, Skaug D 2001. Chewing sticks: timeless natural toothbrushes for oral cleansing. J Periodontal Res 36: 275-284. 